\title{
The New Italian Model Bit Between Current and Future Trends
}

\author{
Maria Chiara Malaguti \\ Department of Public and Private Economics Law, Università Cattolica \\ Sacro Cuore, Milan, Italy; President Of Unidroit \\ mariachiara.malaguti@unicatt.it
}

\begin{abstract}
In 2021, the new Italian Model Bilateral Investment Treaty has been published. It replaced the 2003 Model BIT and can be considered as a significant example of the "new generation of BITs", which try to better balance investor rights with the public prerogatives of States. The Model Treaty also introduces significant innovations as to the conduct of arbitrators and the corporate social responsibility of investors and is also aimed at coordinating Italian and European foreign investment policies. This article offers a view of this new Model BIт and tries to insert it in the broader context of the proposed reforms regarding international investment law and arbitration.
\end{abstract}

\section{Keywords}

new generation IIAS - model BIT - right to regulate - sustainable development goals - sustainable development standards - corporate social responsibility counterclaim - code of conduct for arbitrators - fet standard - definition of investor definition of investment

\section{New trends in International Treaties on Foreign Investments}

At the beginning of 2021, Italy published an upgraded version of its Model Bilateral Investment Treaty (BIT), which had been finalized in the course of 
2020 after various refinements of previous circulated draft versions, ${ }^{1}$ as well as recently tested in pilot negotiations. ${ }^{2}$

This new Model BIT follows the most recent trends for reform. Possibly, it may be considered one of the most overt samples of the current "new generation BIT" for some of its features and embedded principles. Moreover, it includes some mechanisms for management of the agreement that mirror the most recent Free Trade Agreements (FTAs), such as the establishment of a committee to supervise and facilitate implementation of the BIT, as well as carve-out provisions of a similar kind. As part of the European Union (EU, or Union), Italy's Model BIT also features provisions that are the result of the EU policies on Foreign Direct Investments (FDI) and of coordination between the treaties negotiated at EU level and those negotiated by Member States. This text is therefore part of a broader context and represents an example of evolutionary trends in investment agreements that are probably destined to even further develop and upgrade.

\subsection{From One "New Generation" to Another "New Generation" IIA S}

The expression "new generation IIA s" has been used since a couple of decades ago to signal developments in the content of international investment agreements (IIAs) that were commonly identified at a certain point in time against previous agreements of the same kind.

In 2007, UNCTAD qualified as "a new generation of IIAs" an ensemble of treaties since the beginning of the century that, in addition to reconsidering the definition of "investment" to avoid open-ended asset-based lists (considered to be too loose to many extents) and clarifying the meaning of provisions dealing with absolute standards of protection, included for the first time clauses on transparency and improved the working of dispute resolution mechanisms (ISDS). In addition, these would include specific language aimed at emphasizing that the investment promotion and liberalization objectives of IIA s must not be pursued at the expense of other key public policy goals, such

1 After the publication of a draft text in 2016 (Diritto del Commercio Internazionale, 2017, p. 396 ff.), the Legal Service of the Italian Ministry for Foreign Affairs and International Cooperation (MAECI) convened a few meetings with Italian experts and arbitrators to collect comments and suggestions. The text of the Model BIT is available at: <https:// investmentpolicy.unctad.org/international-investment-agreements/treaty-files/6128/ download $>$.

2 The author contributed to the drafting of the Model вIт as an expert to the Legal Service of MAECI. However, the considerations expressed in this work are her own, and should not be interpreted to represent the understanding of the Italian Government, nor bind it to any possible effect. 
as protection of health, safety, the environment, and the promotion of internationally recognized labor rights. ${ }^{3}$ At that stage, however, such latter kind of provisions were still few and not quite articulated.

This came simultaneously with OECD works on the new content of some major standards of protection, ${ }^{4}$ identified indeed to qualify a new generation of agreements, as well as OECD own assessment of such new generation of в гт s, ${ }^{5}$ where it generally noticed that, whereas high protection standards were spreading worldwide, there was an increased recourse to public interest safeguards, as well as various sorts of general exceptions (pertaining to taxation, essential security, the protection of human, animal or plant life or health, the conservation of exhaustible natural resources, prudential measures for the financial sector and culture). ${ }^{6}$ It was the beginning of a longer journey.

Ten years later, UNCTAD elaborated a reform package, including a road map for reform, where it consolidated the results of policy analysis of existing IIAs, leading to a further new generation of agreements. Such reform would more stably reinforce safeguarding of the host state's right to regulate while simultaneously promoting and facilitating investment, ensuring responsible investment, and enhancing systemic consistency. ${ }^{7}$ Very recently, UNCTAD reiterated evidence that most recent "new generation" IIAs oriented reform towards sustainable development, and it further elaborated guidelines on reform to that end. ${ }^{8}$

In parallel, the OECD has confirmed the centrality of international treaties on foreign investments as a tool to contribute to inclusive and sustainable development. " "New generation" treaties would represent effective tools to contribute to address some of the major future challenges, such as climate change, the protection of human rights, the responsible conduct of companies,

3 UNCTAD, Investor-State Dispute Settlement and Impact on Investment Rulemaking, New York and Geneva, 2007, p. 71.

4 OECD, International Investment Law: A Changing Landscape - A Companion Volume to International Investment Perspectives, 2005 (see chapters on Most Favored Nation Treatment, Fair and Equitable Treatment, "Indirect Expropriation" and the "Right to Regulate" in International Investment Law).

5 New Chapter of OECD, International Investment Law: 'A Changing Landscape: Novel Features in Recent OECD Bilateral Investment Treaties', 2006.

6 Ibidem, p. 175.

7 UnCTAD, Reform Package for the international investment regime, New York and Geneva, 2018.

8 UnCTAD, Investment Policy Framework for Sustainable Development, New York and Geneva, 2015; ID., Review of ISDS Decisions in 2019: Selected IIA Reform Issues, IIA Issues Note, No. 1, January 2021.

9 OECD, 6th Annual Conference on Investment Treaties, held virtually on 29-30 March 2021. 
the fight against inequalities, market access. To that end, the OECD once more acknowledged that more and more BITs often contain specific obligations concerning the protection of human rights, of labor, and of the environment, as well as reference to the responsibility of companies to respect such objectives, with direct reference also to the OECD guidelines for multinationals. ${ }^{10}$

Thus, trends have been evidenced in the last decades towards a better articulation of basic protection standards, which would add certainty to investment law, but in parallel also the widening of states' right to regulate, in particular to protect human rights, the environment, and some other principles for sustainable development, as well as an increased attention for social responsibility of investors. Furthermore, the international community seems to go towards recommending and supporting the use of investment agreements to directly contribute to the goals of sustainable development.

While the insertion of principles and obligations to address protection of general interests in recent BITs is indeed a fact, the transformation of IIAS into sustainable development tools is probably far to come, and possibly will qualify future generations of investment treaties. This will be considered at the conclusion of this contribution. However, some evidence of a change in optic is yet detected and can possibly be traced also in the Italian Model BIт.

The EU Framework on FDI s and its "Open, Sustainable and Assertive Trade Policy"

On the other side, it is impossible to fully understand the architecture and content of the new Italian Model BIT by extrapolating it from the context of the Union. As known, competencies on FDI since the Lisbon treaty have been centralized at EU level. The new Italian Model вIт thus contains provisions dictated by its participation into the Union. ${ }^{11}$ Moreover, also in the fields where Member States maintain some room for manoeuvre, the Model BIT responds to a common understanding by the Union and the Member States on many issues, including on sustainability and socially responsible investments. ${ }^{12}$

10 For some indications on these findings, see oEcD, The Future of Investment Treaties. Background Note on Potential Avenues for Future Policies, 29 March 2021. Within such context, the OECD is developing an FDI Qualities Policy Toolkit, which is expected to assist governments in better combining investment policies with other sustainable policies.

11 Regulation (EU) No. 1219/2012 of the European Parliament and of the Council of 12 December 2012 establishing transitional arrangements for bilateral investment agreements between Member States and third countries, OJEU L 351, 20.12.2012, p. 40. As known, the Commission authorizes the Member State to open formal negotiations, as well as to sign and conclude a BIT.

12 See Communication from the Commission to the European Parliament, the Council, the European Economic and Social Committee and the Committee of the Regions - Trade 
From 12 March 2020, the Commission publishes its implementing decisions on authorizations granted to individual EU members for BIT s. Such decisions clearly define the perimeter of the Member States negotiating powers, which thus also affect the content of any of their Model BIт s. ${ }^{13}$ As it is shown by the common language of the published decisions to authorize initiation of investment negotiations, ${ }^{14}$ Member States are requested to include clauses reflecting in particular the following standards and rules: (a) fair and equitable treatment, including a prohibition of unreasonable, arbitrary or discriminatory measures; (b) national treatment; (c) most-favored nation treatment that would prevent the importation of standards of treatment and procedural rights from other investment agreements, and that would not oblige them to extend to investors of the other contracting party the benefit of the treatment resulting from a process of economic integration; (d) protection against direct and indirect expropriation, including the right to prompt, adequate and

Policy Review - An Open, Sustainable and Assertive Trade Policy, сом (2021) 66 final (18 February 2021). This document contains many elements that are not reflected in current instruments, but that may form the basis for further upgrading: "As reflected in the European Green Deal, combatting climate change and environmental degradation is the EU's top priority. All EU policies need to contribute but progress will depend on global partners, on large emitters and polluters, being ready to increase their level of ambition. Trade policy will have an important supporting role. The Commission's resolve for the next decade is to ensure that trade tools accompany and support a global transition towards a climate neutral economy, including accelerating investments in clean energy, and promote value chains that are circular, responsible and sustainable. This includes promoting responsible business conduct and the respect of environmental, human rights and labour standards. At the same time, it means creating the conditions and opportunities for sustainable products and services. [... F] or future trade agreements, the Commission will propose a chapter on sustainable food systems. The EU will propose that the respect of the Paris Agreement be considered an essential element in future trade and investment agreements. In addition, the conclusion of trade and investment agreements with G2o countries should be based on a common ambition to achieve climate neutrality as soon as possible and in line with the recommendations of the Intergovernmental Panel on Climate Change (IPCC)" (3.2.2). Furthermore: "The Commission will propose a new sustainable investment initiative to partners or regions in Africa and the Southern Neighbourhood interested in doing so. This could be done in the form of stand-alone investment agreements or as part of the modernisation of existing trade agreements. To maximise their impact and facilitate implementation, these agreements will be designed together with EU development cooperation tools to support investment and, wherever feasible, with a Team Europe approach to ensure synergies with EU Member States, the private sector, civil society, and all relevant actors" (3.2.5.).

13 Available at: <https://trade.ec.europa.eu/doclib/cfm/doclib_section.cfm?sec=184>.

14 See for instance authorizations to Hungary of 12 March 2020, available at: <https://trade. ec.europa.eu/doclib/docs/2020/april/tradoc_15870o.pdf>, and to Spain of 29 May 2020, available at: <https://trade.ec.europa.eu/doclib/docs/2020/june/tradoc_158770.pdf>. 
effective compensation; (e) full protection and security of investors and investments; (f) effective transfer of capitals and payments by investors, consistent with the Treaty on the Functioning of the European Union (TFEU); (g) effective dispute resolution mechanism; (h) prohibition of investment enhancement by lowering or relaxing domestic environmental or labor legislation and standards, or by failing to effectively enforce such legislation and standards; (i) reference to human rights and sustainable development and promotion of internationally recognized standards of corporate social responsibility, such as OECD Guidelines for Multinational Enterprises and the UN Guiding Principles on Business and Human Rights.

The negotiating Member State must also ensure that none of the provisions of the agreement in question prevent it from fulfilling the obligations resulting from its membership of the Union. In particular, it must ensure that the provisions of the agreement contain language clarifying that the prospective agreement shall not be construed as requiring the Member State to compensate an investor for discontinuing the granting of state aid or requesting its reimbursement, where such action stems from an administrative or a judicial decision, nor prevent it or the Union from adopting or maintaining reasonable measures for prudential reasons.

The Member State must equally ensure that the prospective agreement contains language clarifying that it is without prejudice to the right of the parties, and of the Union, to adopt and enforce, in accordance with their respective competences, measures necessary to pursue legitimate public policy objectives such as social, environmental, security, public health and safety. These provisions are supported by the EU Commission to ensure the consistency of the common commercial policy in terms of basic principles and objectives of the external relations of the EU, as required by Article 207 TFEU. Those principles - enshrined in Article 3(5) Treaty on the European Union - comprise, inter alia, sustainable development, fair and equitable trade and safeguard of human rights. This is possibly the entry door to path the way towards a more articulated combination of EU and Member States' IIAs to build the "Open, Sustainable and Assertive Trade Policy" that the Commission recently declared shall shape the coming years. ${ }^{15}$

Within such background, Italy undertook to upgrade its previous Model BIT with two declared main goals: to adjust a few definitions and rules that had become obsolete or had proven to need redrafting for better accuracy, and to reflect achievements of the international agenda on sustainable investments. ${ }^{16}$

15 See cit. supra note 13 .

16 Petrang eli, Silvi and MALAg Uti, Why and how to upgrade the Italian Model BIT, Diritto del Commercio Internazionale, 2017, p. $389 \mathrm{ff}$. 


\subsection{The 2003 Model BIT}

The previous Italian Model Bit dates back to 2003. The old Model was much less articulated than the new one: consideranda were limited, and only mentioned the goal of establishing favorable conditions to enhance economic cooperation between the two contracting parties through mutual encouragement and protection of investments, which would contribute to stimulate business ventures able to foster the prosperity of both parties. Definitions were broadly those that one would expect to find at the time of its drafting. However, some of these required upgrading. In particular, the definitions of both "investment" and "investor" called for refinement. Moreover, standards of protection had to be improved and better articulated: the 2003 Model BIT did not contain a clear-cut definition of the standard of "fair and equitable treatment" (FET), but rather referred to "just and fair treatment", with no additional articulation. Except for a specific provision on expropriation, other standards of treatment today frequently found were missing. There was thus a need for upgrading the provisions that are traditionally embedded in a BIT to reduce ambiguities and loopholes and take stock of developments in interpretation of those concepts by the international community, arbitral tribunals, and doctrine, as it customarily occurs.

The new Model BIT attempts to provide a consistent set of definitions and rules aimed at protecting foreign investments and reducing uncertainty in interpretation. However, the new Model also contains various additional provisions. In the first place, it boosts implementation of international standards on health, protection of the environment, and human rights by the host state, as well as by investors. To that end, in addition to consideranda introducing such principles as a criterion for interpretation of the substantive provisions of the BIT, also specific obligations are set. A provision also includes the possibility for the host state to start a counterclaim if the investor has proven not having respected some of such obligations. In the second place, the Model BIT contains carve out provisions for prudential regulation and the restructuring or rescheduling of public debt. These provisions take stock of the current trends by international standard setting bodies to ensure financial stability, and partially mirror clauses embedded in most recent FTAs negotiated by the Union. Finally, the Model BIT contains as an annex a code of conduct for arbitrators.

One clarification at this stage is mandatory, although obvious: Model BITs are nothing more than a text facilitating the starting of negotiations of an agreement. In the specific context of the Union, when the EU Commission authorizes negotiations with a specific country, to avoid that then negotiations take too far from a kind of agreement that the Commission would be ready to then authorize as finalized, the submission of a Model вгт as the canvas for negotiations 
helps enormously. Moreover, it is undeniable that the use of a Model BIт helps consistency in the agreements undertaken by a specific country at macro-level. However, a Model BIT is written to give only high level guidelines on the kind of protection to be granted to investments, as well as on the kind of obligations and mechanisms that are considered appropriate for investment policy, whereas concretely binding provisions are only those coming from each individual вIт that shall be finally signed, which will vary according to situations and the other party's agenda. The reason why this obvious clarification is in fact needed, is because in reading Model BITs one might find alternative provisions, or provisions that are flagged as those requiring more accurate understanding of their effects under the circumstances, or even a structure of a clause that contains some ambiguities on the concrete openness to a principle. When assessing a Model BIT, one must thus look at its overall structure and at the developments against previous drafts, rather than at individual aspects per se. This will be the approach followed in the coming pages, to show the novelties as perceived by the author and the perspectives that the new Italian Model BIT opens for further developments and as a sign of possible general present and future trends in international treaties on foreign investments.

\section{Main Novelties of the New Italian Model BIT}

\subsection{Definitions of "Investor" and "Investment"}

The Model BIT contains an asset-based definition of investment (Article 1(1)). However, to be covered by the Model Biт the investment must have a certain duration, the commitment of capital or other resources, and the assumption of risk. Contrary to those agreements that contain no qualification of "investment" but only list items to be considered as potential investments (where the material qualities of an investment are left to the arbitral tribunal to determine), this definition crystallizes what an investment is. The language of the Model BIT reflects that of the EU-Canada Comprehensive Economic and Trade Agreement (CETA $)^{17}$. Moreover, unlike other agreements such as the Model B Iт adopted in 2012 by the United States (2012 US Model в вт), ${ }^{18}$ which

17 Canada-European Union Comprehensive Economic and Trade Agreement - Chapter Eight: Investment, Art. 8.1. available at: <https://www.international.gc.ca/trade-commerce/tradeagreements-accords-commerciaux/agr-acc/ceta-aecg/text-texte/o8.aspx?lang=eng > .

18

2012 US Model Bilateral Investment Treaty, Art. 1, available at: <https://ustr.gov/sites/ default/files/BIT\%2otext\%2ofor\%2oACIEP\%2oMeeting.pdf $>$. The Model BIт qualifies an investment as requiring commitment of capital or other resources, the expectation of gain or profit, or the assumption of risk, while a certain duration is not required. 
includes an imperative list of items, the one contained in the Italian Model BIT is open-ended. On the other hand, reference to direct or indirect control (which was not present in the 2003 Model BIT) widens the scope of the treaty to also include cases where the investor does not directly own the relevant assets.

The definition of "investor" includes legal entities that are constituted under the laws of the contracting party, and that have their head office, as well as real business activities in the territory of the same country (Article 1(4)). This prevents the abusive establishment of a shell company in a country for the sole purpose of benefitting from the protection of the BIT and establishes a genuine link between the investor and the contracting party. ${ }^{19}$

Finally, to complete the set of definitions relating to the scope of rules on investment law, the Model Biт contains definitions of "covered investment" (Article 1(2)) as well as of "control" (Article 1(3)), and "undertaking", ${ }^{20}$ none of which was present in the previous Model Biт.

\subsection{Standards of Protection}

\subsection{1 $\quad$ Fair and Equitable Treatment}

Article 3 of the Model BIT refers to the FET standard. To avoid ambiguities in the actual content of the standard, it first qualifies the scope of FET and further lists those acts that would breach it. This approach somehow mirrors the FET standard in the CETA as well as other Model investment agreements, such as

19 This language is found also in the Art. 2(2)(b) of the 2019 Model BIT by the BelgiumLuxemburg Economic Union referring to "their headquarters or their real economic activities", available at: <https://investmentpolicy.unctad.org/international-investmentagreements/treaty-files/5854/download $>$. Analogous, although not coincident language can be found in the Dutch Model BIT to mitigate the risk of forum shopping (Art. $1(b)$ (ii): "substantial business activities". However, the Dutch Model BIT also includes a list of situations amounting to "substantial business activities" and establishes that "[t]hese indications should be assessed in each specific case, taking into account the total number of employees and turnover of the undertaking concerned, and take account of the nature and maturity of the activities carried out by the undertaking in the Contracting Party in which it is established" (Art. 1(c)). The analysis of the use of the expression "real business activities" against "substantial business activities" is outside the scope of a contribution of this kind. However, in both cases it is evident that the intent is to stress the existence of a real connection between the investor and its home country. For a general, although not recent survey, see OECD, Definition of Investor and Investment in International Investment Agreements, in International Investment Law: A Changing Landscape - A Companion Volume to International Investment Perspectives, 2008.

20 The definition of "undertaking" extends to entities for profit as well as not for profit, privately or governmentally owned, with or without legal personality under applicable law. This substitutes the definition of "legal person" contained in the 2003 Model BIT. 
the 2012 US Model вгт. ${ }^{21}$ A similar language is also found in the 2019 Dutch Model вгт. ${ }^{22}$ The list broadly reflects the three macro-categories generally accepted as a minimum standard of treatment, that is to say: $\mathrm{i}$ ) denial of justice or fundamental breach of due process, ii) manifest arbitrariness or abuse, and iii) targeted discrimination. However, Article 3 also includes an explicit reference to legitimate expectations. This mirrors the clause inserted in the CETA as well as in the Dutch Model BIT, ${ }^{23}$ that legitimate expectations of investors can be considered by tribunals in situations where a specific representation was made by the host State to an identifiable investor, and where the investor had relied on such representation. ${ }^{24}$

\subsubsection{Sustainable Development and the Host State's Right to Regulate} Standards of protection yet find a balance in the right of the host state to regulate to achieve legitimate policy objectives. Article 5 contains an open-ended list of such objectives, including the protection of human rights, public health, safety, the environment, public moral, financial stability, social or consumer protection, or the promotion and protection of cultural diversity.

These objectives and the recognition of the states' right to regulate to achieve them are also stated in the consideranda, where contracting states also reaffirm their commitment to sustainable development and to promote the development of international economic cooperation in such a way as to contribute to sustainable development in all its dimensions, that is to say: economic, social, and environmental. This is completed by the commitment, within promotion and protection of investments, to encourage socially responsible behaviors by investors, in line with international standards and best practice, as well as to promote investments in the contracting parties' territory by lowering protection of the environment and social rights (Article 2(5)).

The right to regulate interacts with the standards of protection. The rights of investors and their investments are not infringed when general measures by the host state are non-discriminatory, reasonable, and proportionate (Article $5(2))$. On the other side, non-discrimination, reasonableness, and proportionality are the standards that the Model BIT calls upon when qualifying the FET in Article 3 and before getting to the list of measures concretely representing violations of the standard. ${ }^{25}$

\footnotetext{
21 Ceta Art. 8.10(2); US Model BIT, Art. 5 (Minimum standard of treatment).

22 Netherlands Model Investment Agreement, Art. 9.

23 Ceta Art. 8.10(4); Dutch Model Law, Art. 9(4).

24 Art. 3 also contains a provision on the standard of full protection and security, unambiguously limiting it to physical security (para. 5).

25 "Neither Contracting Parties shall take unjustified, unreasonable or discriminatory measures [...]" (Art. 3(1)).
} 
Nowadays, provisions of this kind are not extraneous to Model BITs in the Union. One can find similar clauses in the Model BITs of 2019 by the Slovak Republic, ${ }^{26}$ the Belgium-Luxemburg Economic Union (BLEU ${ }^{27}$ and the Netherlands. ${ }^{28} \mathrm{~A}$ similar provision is found in agreements negotiated by the European Commission, such as CETA, ${ }^{29}$ or the EU-Vietnam Free Trade Agreement. ${ }^{30}$

\subsubsection{Prudential Carve-Out and the Specific Clause for Public Debt}

Legitimate public objectives also include financial stability. An additional clause is yet proposed in the Model BIT to shield state measures regulating financial markets, as long as such measures are reasonable. Financial stability would not be the sole objective justifying such regulation, more widely founded upon prudential requirements, ensuring in turn integrity, as well as stability not only of the financial market, but also of individual financial institutions, domestic or cross-border, or protecting investors, depositors, policyholders. This approach is common to other recent EU Member States' Model вітs. ${ }^{31}$ Similar provisions were however already present in the 2012 US Model віт: Article 20 on Financial Services, even contemplates the direct involvement of financial authorities in any dispute that could arise under this title to ensure adequate consideration of the specificities of this sector. ${ }^{32}$

A specific provision is then devoted to restructuring and rescheduling of public debt (Article 6). This provision is to understand within the long series of arbitral awards in case of default of a state, also interfering with remedies otherwise established by supra-national authorities. ${ }^{33}$ Financial integrity, financial stability and prudential standards are not customarily considered to be part of sustainable development. However, they nowadays represent the pillars for governance of (international) financial markets. The new Italian Model

26 Agreement between the Slovak Republic and ... For the Promotion and Reciprocal Protection of Investments, Art. 4, available at: <https://investmentpolicy.unctad.org/ international-investment-agreements/treaty-files/5917/download $>$.

27 Art. 15 .

28 Art. 2(2).

29 Art. 8.9(1).

30 Free Trade Agreement between the European Union and the Socialist Republic of Vietnam, Art. 8.1(1), available at: <https://eur-lex.europa.eu/legal-content/EN/TXT/PDF/?uri=OJ:L:2O2 o:186:FULL\&from $=$ EN\#page $=46>$.

31 See in particular Art. 12 of the Slovakia Model Law. See also BLEU Model BIT, Art. 3(4). The Dutch Model BIT, on its side, instead than referring in general to financial stability - as Italy and BLEU do - rather refers to "prudential financial reasons": Art. 2(2).

32 See also CETA Art. 13.16, which contains the same language as the prudential carve out of the Italian Model BIт. Chapter 8 of the CETA does not apply to financial services.

The 2019 Dutch Model Bit contains a specific Protocol on Public Debt. 
BIT thus contains the first signs of also the attempt to address the interference between international investment law and international financial law.

\subsection{Socially Responsible Investors}

\subsubsection{Corporate Social Responsibility}

Explicit reference to "Corporate Social Responsibility" (CSR) is found only in the Model BIT's consideranda. ${ }^{34}$ However, the substance of commitments under CRS is embedded in a provision dictating compliance by investors and their investments with the legislation of the host state in the fields that populate sustainable development and are addressed by international standards. ${ }^{35}$ Moreover, investors and their investments are requested to strive, through their management policies and practices, to contribute to sustainable development of the host State and to promote gender equality.

While until very recently it was rare to find such reference in a BIT, nowadays these references are becoming more and more frequent. In the EU, the most recent Model BITs do contain direct obligations for investors. In the BLEU Model BIT, a specific chapter is dedicated to investment and sustainable development (Chapter III), where - in addition to various commitments by the two contracting parties -, a specific provision is devoted to CSR (Article 18). Equally, the Dutch Model BIT contains a section on sustainable development, composed of a first provision on states' commitments (Article 6), and a second one containing investors/investments' commitments (Article 7). Compared to the one in the BLEU Model BIT, the Dutch clause rather names the various international standards that it relies upon, and specifically includes investors' duty to perform an adequate due diligence to identify, prevent, mitigate, and

34 "ENCOURAGING enterprises operating within their territory or subject to their jurisdiction to respect internationally recognized guidelines and principles of corporate social responsibility, including the OECD Guidelines for Multinational Enterprises, and to pursue best practices of responsible business conduct;"

35 "(i) Law concerning payment of wages and minimum wages, employment of contract labour, prohibition on child labour, special conditions of work, social security and benefit and insurance schemes applicable to employees; (ii) environmental law applicable to the Investment and its business operations; (iii) law relating to conservation of natural resources; (iv) law relating to human rights, as set forth in the Universal Declaration of Human Rights; (v) law of consumer protection and fair competition; (vi) relevant national and internationally accepted standards of corporate governance and accounting practices; and (vii) information sharing requirements of the host State concerning the compliance with laws and regulations on human rights, environmental protection and labor laws for the Investment in question and in the corporate history and practices of the Investment or Investor, for purposes of decision making in relation to that Investment or for other purposes." 
account for the environmental and social risks and impacts of their investments. Finally, the Dutch Model вгт makes investors liable in accordance with the rules concerning the jurisdiction of their home state for the acts or decisions made in relation to the investment where such acts or decisions lead to significant damage, personal injuries or loss of life in the host state (although the Model BIT itself does not illustrate how this principle would concretely apply and how significant damages would have to be assessed).

\subsubsection{Counterclaim}

The Italian Model вIт is possibly less detailed than the Model Biт s just named. However, provisions contained in its clauses seem to cover the same areas and establish the same principles. Moreover, while in both the BLEU and the Dutch Model вітs the dispute settlement mechanisms established in the model treaty do not apply to the chapter/section on sustainable development, the Italian Model BIT does not make such distinction. ${ }^{36}$ On the opposite, it permits the host state, if one of the obligations of the investors/investments has been breached, to raise a counterclaim against the investor. ${ }^{37}$ Although none of the provisions in the Model BIT are mandatory, this specific provision is specifically flagged in the text as optional to signal to negotiators the specialty of such clause and thus the need to deeper assess the consequences of the application of such provision according to the circumstances. ${ }^{38}$

The above specific aspect left aside, to the author's knowledge, the Italian Model BIT is one of the very few that expressly refer to the use of the instrument of counterclaim to make the respect of legislation on sustainable development enforceable under the treaty itself. ${ }^{39}$

36 See instead in the Dutch Model BIT the faculty for the tribunal to consider violations of some international standards when granting damages (Art. 23).

37 The application of this provision is conditional upon a withdrawal of disputing rights before the national courts by the host state.

38 This would also facilitate negotiations to for instance exclude a possibly controversial letter listed in this provision, that is to say: letter vi), that refers to soft law instruments, although letter vi) may be understood as referring to international standards as adopted in the relevant legal order.

39 See to that end the COMESA Investment Agreement (2007), Art. 28(9): "A MemberState against whom a claim is brought by a COMESA investor under this Article may assert as a defence, counterclaim, right of set off or other similar claim, that the COMESA investor bringing the claim has not fulfilled its obligations under this Agreement, including the obligations to comply with all applicable domestic measures or that it has not taken all reasonable steps to mitigate possible damages", available at: <https://investmentpolicy.unctad.org/ international-investment-agreements/treaties/treaties-with-investment-provisions/3225/ 
2.4.1 Content and Role of the Code Attached to the Model BIT

Article 14 of the Model BIт, on settlement of disputes between investors of a contracting party and the other contracting party, also contains a few provisions on the effects of the code for arbitrators. In the first place, arbitrators appointed by the disputing parties must be independent, serve in their individual capacities and not be affiliated with the government of either of the contracting parties. All arbitrators are requested to have specialized knowledge of or experience in public international law and international investment law, or in the settlement of disputes under international investment agreements. They must comply with the code of conduct adopted by the contracting parties (Article 14(5)).

In the second place, when a disputing party considers that an arbitrator does not comply with the requirements of the code, it can send a notice of challenge to the appointing authority. The Model BIт establishes a procedure for challenge, and if the appointing authority decides that the arbitrator has not complied with the requirements of the code, such arbitrator must resign from the tribunal (Article 14(6)).

The code covers arbitrators, as well as candidates and assistants and staff of the arbitrator, although to different extents. Arbitrators and candidates must avoid not only impropriety, but also the appearance of impropriety, must be independent and impartial, and avoid any direct or indirect conflict of interest. They must respect principles of disclosure, perform their duties with fairness and diligence, and respect confidentiality. Former arbitrators must avoid actions that may create the appearance that they were biased in carrying

comesa-investment-agreement $>$. This text has been upgraded in the course of the years and apparently a new draft was adopted in 2017 , which is not publicly available. See also African Union Commission, Draft Pan-African Investment Code (2016), Art. 43, available at: <https://au.int/sites/default/files/documents/32844-doc-draft_pan-african_investment_ code_december_2016_en.pdf >. Special consideration should also be given in the analysis of the above matters to the very recent Model BIT of Morocco (2019). In this Model BIT, the tribunal addressing disputes under the relevant BIт must take into consideration the violation of investor's obligations in the quantification of damages. Indeed, Art. 20(5) reads: "A tribunal established under Section vi of this Agreement shall, when determining the amount of compensation, take into account the failure by the investor to comply with its commitments referred to in paragraph 20.4 of this article" (translation from French by the author and emphasis added). For the sake of completeness, Art. 2o(4) states: "Investors shall manage or operate their investments in accordance with international obligations on human and labor rights, responsible business conduct, protection of health and the environment, in accordance with mitigation objectives and adaptation to climate change" (translation from French by the author), available at: <https://investmentpolicy.unctad.org/ international-investment-agreements/treaty-files/5895/download>. 
out their duties or derived any advantage from the decision or ruling of the tribunal.

\subsubsection{The Code of Conduct of the Italian Model BIT versus the Draft ICSID/UNCITRAL Code}

As known, one of the exercises within the undergoing international works on ISDS reform concerns the elaboration of a code of conduct for adjudicators. A first draft was jointly produced by UNCITRAL and ICSID ${ }^{40}$ and was initially discussed at the session of UNCITRAL Working Group III on ISDS reform (WG III) that took place in February 2021. ${ }^{41}$ Since works have not been completed, it is impossible to predict how this code will exactly look like and to what extent it will apply and/or possibly substitute existing codes of conduct, which are not harmonized. However, the draft as produced by UNCITRAL and ICSID and the preliminary discussions already give some indications.

Leaving aside the major point of discussion, i.e.: whether a single code of conduct can equally apply to ad hoc arbitrators as well as to adjudicators in a permanent court (since the negotiations navigate between these two poles), UNCITRAL and ICSID propose to apply it - as the Italian Code does - to adjudicators, candidate adjudicators and their assistants. ${ }^{42}$ Adjudicators must at all times be independent and impartial, and avoid any direct or indirect conflicts of interest, impropriety, bias and appearance of bias. They must display the highest standards of integrity, fairness and competence, act with diligence, and comply with any confidentiality and non-disclosure obligations (Article 3).

As for conflicts, the ICSID and UNCITRAL draft code imposes to adjudicators to avoid any direct or indirect conflict of interest, and to disclose any interest, relationship or matter that could reasonably be considered to affect their independence or impartiality (Article 5). To this end too, the Italian code attached to the Model BIT broadly mirrors the ICSID and UNCITRAL draft code, although it does not contain a specific list of circumstances that might have to be disclosed, which the draft code by ICSID and UNCITRAL instead contains. ${ }^{43}$

40 Available at: $<$ http://undocs.org/en/A/CN.9/WG.III/WP.2O1>.

41 At the time of completion of this contribution (31 May 2021), a second draft had been circulated, whose changes against the first draft do not affect what is described here. For both texts, see UNCITRAL website available at: <https://uncitral.un.org/en/working_groups/3/ investor-state>.

42 Responsibility that assistants respect the provisions of the code is put on the adjudicators.

43 "(a) Any professional, business and other significant relationships, within the past [five] years with: (i) The parties [and any subsidiaries, parent-companies or agencies related to 
Finally, the ICSID and UNCITRAL draft code contains rules for the limiting of multiple roles. Article 6 establishes that adjudicators must refrain from acting (or alternatively disclose that they act) as counsel, expert witness, judge, agent or in any other relevant role at the same time (or in the alternative, within a specific period) as they are acting on matters that involve the same parties. The draft leaves the possibility that this be extended also to the same facts, or the same treaty. These provisions, which have been highly discussed between those who would like to see such prohibitions in place and those who would instead limit the obligations of adjudicators to one of disclosure, are not contemplated in the Italian Model.

In fact, although the two text broadly correspond in content, the Italian code tends to be more general, and relies more on disclosure than on specific impediments for an arbitrator to sit in a proceeding. Moreover, focus seems to be predominantly on the independence of an arbiter. Self-interest, outside pressure, political considerations, public clamor, loyalty to a disputing party or a non-disputing party, or fear of criticism are all mentioned (Article 10 of the Italian Code) as forms of pressure that individual arbitrator should be able to escape to duly perform their role. These qualities prevail over more mechanic determinations of conflicts or incompatibilities.

\section{$3 \quad$ Current and Future Trends: Once More BIT s at a Crossroad?}

Answering the question whether the new Italian Model BIT responds to new trends, opens several issues. In the first place, actual trends should be clearly detected. Model вітs per se help to extract some common features in the general understanding of states, but any serious consideration should not be founded upon these texts, but rather on adopted treaties. Moreover, developments in interpretation of those treaties by the contracting parties should also

the parties]; (ii) The parties' counsel; (iii) Any present or past adjudicators or experts in the proceeding; (iv) [Any third party with a direct or indirect financial interest in the outcome of the proceeding]; (b) Any direct or indirect financial interest in: (i) The proceeding or in its outcome; and (ii) An administrative proceeding, a domestic court proceeding or another panel or committee proceeding that involves questions that may be decided in the ISDS proceeding; (c) All ISDS [and other [international] arbitration] cases in which the candidate or adjudicator has been or is currently involved as counsel, arbitrator, annulment committee member, expert, [conciliator and mediator]; and (d) A list of all publications by the adjudicator or candidate [and their relevant public speeches]" (Art. 5(2)). Individual circumstances have been the subject of various criticisms in the February 2021 session of WG III. 
be assessed. To that end, the new Italian Model BIT introduces, in addition to a specific provision on amendments to the agreement (Article 17), provisions on the management of the treaty through the establishment of a committee (Article 12), expected to meet at least once a year. This Committee, among other tasks, holds that of developing recommendations on review of the content of the FET standard (Article 3(3)), which the parties shall then consider. The working of such committees, producing upgrading of each agreement under its own paths, may lead these to further depart from the original Model BIT.

In the second place, a correct assessment should extend to the various regions of the world. Already in 2012, the SADC member states adopted a BIT template with an extremely detailed commentary. ${ }^{44}$ India adopted a new Model BIT in 2016, ${ }^{45}$ and in 2020 it signed an investment cooperation and facilitation treaty with Brazil that combines the visions of the two countries (Brazil's latest model investment agreement dates 2015). ${ }^{46}$ In the same year (2016) the Russian Federation adopted a document on general approaches to the conclusion of international agreements on the promotion and protection of investments. ${ }^{47}$ In 2019, Morocco adopted a Model BIT that contains various provisions on standards of protection as well as sustainable development. ${ }^{48}$ At the very time this contribution is concluded (31 May 2021), the new Canada Foreign Investment Promotion and Protection Agreement (FIPA) is announced. ${ }^{49}$ These are just the most recent Model BITs that were made public.

With the above caveats, the new Italian Model BIT does respond to new trends, which in fact can be found in several of the mentioned most recent Model BITs, although each possibly articulating differently in respect of

44 SADC Model Bilateral Investment Treaty Template with Commentary, July 2021, available at: <https://www.iisd.org/system/files/meterial/6th_annual_forum_sadc_model_template. pdf?q=sites/default/files/meterial/6th_annual_forum_sadc_model_template.pdf >.

45 Available at: $<$ https://dea.gov.in/sites/default/files/ModelBIT_Annex_o.pdf $>$.

46 Available at: <https://investmentpolicy.unctad.org/international-investment-agreements/ treaties/bilateral-investment-treaties/4910/brazil---india-bit-2020->. The Brazil Model Cooperation and Facilitation Investment Agreement is available at: <https:// investmentpolicy.unctad.org/international-investment-agreements/treaty-files/4786/ download $>$.

47 Available at: <https://investmentpolicy.unctad.org/international-investment-agreements/ treaty-files/6oog/download $>$.

48 See cit. supra note 40.

49 <https://www.international.gc.ca/trade-commerce/trade-agreements-accordscommerciaux/agr-acc/fipa-apie/index.aspx?lang=eng $>$. 
individual issues. As said, it is possibly one of the most overt examples of the current "new generation".

On the other side, more and more in recent years it is heard that investment agreements are at a crossroad. ${ }^{50}$ This is attributed to various - differing - factors, from the changing geography of investments (leading countries to reconsider each its domestic objectives and policies), to the new interests and values at stake. The recent crises, latest of which the one caused by the global pandemic, challenged many of the premises of existing governance of trade and commerce, and have thus sharpen the urgency for rediscussing the role of investment agreements, and the relation between trade and investment policy, on the one side, and other policies, on the other.

To that end, a recent study in preparation for the mentioned 6th Annual Conference on investment treaties of $\mathrm{OECD},{ }^{51}$ delving on future policies in investment agreements, while acknowledging the above trends, proposes several potential avenues to respond to new challenges and a profoundly different environment for international investment, and preconizes potential new roles for investment treaties within trade policies. These would contribute to the strengthening of market access and investment facilitation, as well as simultaneously contributing to sustainable development and responsible business conduct, and possibly establish a more flexible range of remedies and implementation mechanisms for a broader canvas of interests. ${ }^{52}$

The discussions held in March 2021 at the 6th OECD Annual Conference on investment treaties are the starting point for further works and conceptualization that might still take various steps for the achievement of shared understandings of these issues. However, considerations for new roles of domestic BIT s might have a more circumscribed and thus concrete context at regional level.

Italy is part of the EU. Competences on FDI are part of the centralized common commercial policy of the Union, although some matters traditionally covered by investment agreements still fall within the Member States' powers. The EU Commission has also decided to 'decentralize' some FDI measures by leaving Member States to undertake investment agreements with countries with

50 The works to that end are many. For a quick reference, see SING H and ILGE (eds.) Rethinking Bilateral Investment Treaties. Critical Issues and Policy Choices, Amsterdam, 2016, available at: <https://www.somo.nl/wp-content/uploads/2016/o3/Rethinking-bilateral-investmenttreaties.pdf $>$.

$51 \quad$ See cit. supra note 10.

$5^{2}$ OECD, The Future of Investment Treaties. Background Note on Potential Avenues for Future Policies, edited by GAUKRODGer, 2021, available at: <http://www.oecd.org/daf/inv/ investment-policy/Note-on-possible-directions-for-the-future-of-investment-treaties.pdf $>$. 
which the Union does not intend to conclude one. This will possibly take to a reconsideration of these instruments within a more general assessment of policies and measures in trade by the Union and its Member States. The mentioned very recent Communication of the Commission entitled Trade Policy Review - An Open, Sustainable and Assertive Trade Policy ${ }^{53}$ speaks of a re-orientation of trade policy, which would respond to a more sustainable growth model as defined by the European Green Deal and the European Digital Strategy and combine resilience and competitiveness with sustainability and fairness as well as assertiveness and rules-based cooperation, together with promotion of sustainable and responsible value chains. Indeed, at the time of completion of this contribution, it is understood that the European Commission is making a further assessment of the Italian Model BIT (expectedly together with the BIT s of other Member States) against its new policy trends. This might take to further reinforce provisions on sustainable development and CSR, possibly following the Dutch or BEU Models that have been discussed.

These objectives will have an impact also on the policies on FDI and will possibly rise the question of the specific role of Member States' investment agreements in such context. What appears to be specifically relevant, is that strengthening of investments, and consequently also investment protection standards and legal certainty for foreign investors, shall be combined with common obligations and responsibilities for (economic, social, environmental) sustainability in ways that might further upgrade the newest generation of віт s. The current content of the latter generation of вIт s, to which the Italian Model BIт belongs, will yet work as the primary point of departure.

53 See cit. supra note 13 . 